\title{
Knowledge, attitudes and practices for the prevention of diabetic foot
}

\author{
Conhecimento, atitudes e práticas de \\ medidas preventivas sobre pé diabético \\ Conocimiento, actitudes prácticas y de escrituras \\ de la prevención en pie diabético
}

\author{
Natalia de Sá Policarpo ${ }^{a}$ \\ Jayne Ramos Araujo Moura ${ }^{b}$ \\ Eugênio Barbosa de Melo Júnior \\ Paulo César de Almeidad \\ Suyanne Freire de Macêdo \\ Ana Roberta Vilarouca da Silva ${ }^{f}$
}

\begin{abstract}
The purpose of this study was to identify the knowledge, attitudes and practices for the prevention of diabetic foot in patients with diabetes mellitus type 2. This study was based on a cross-sectional survey conducted in two Family Health Units, in the city of Picos $\mathrm{PI}$, Brazil, with 85 diabetics of both sexes, by means of a semi-structured Knowledge, Attitude and Practice questionnaire. There was a predominance of females in the study (62.4\%). On the topic of foot care, $49.4 \%$ had no knowledge on hygiene or what to observe in their feet. In relation to nail care, $56.5 \%$ were unaware of the correct way to cut nails. Regarding attitudes, $80 \%$ were willing to engage in self-care. In terms of practice, results showed that activities such as washing, drying, moisturizing and massaging were not executed together. It is therefore necessary to develop educational strategies to create awareness, both for diabetics and health professionals, on the effective prevention of diabetic foot.
\end{abstract}

Descriptors: Diabetes Mellitus, type 2. Diabetic foot. Health knowledge, attitudes, practice health.

\section{RESUMO}

Objetivou-se identificar o conhecimento, as atitudes e as práticas voltadas à prevenção do pé diabético em pacientes com diabetes mellitus tipo 2. Trata-se de pesquisa transversal desenvolvida em duas Unidades de Saúde da Família, no município de Picos, PI, com 85 diabéticos de ambos os sexos, mediante o uso de um formulário semiestruturado, do tipo inquérito sobre Conhecimento, Atitude e Prática. Houve predominância do sexo feminino no estudo (62,4\%). Sobre o conhecimento dos cuidados com os pés, 49,4\% não sabiam como se faz a higiene e o que se deve observar nos pés. Nos cuidados com as unhas, 56,5\% desconheciam o corte correto. Em relação às atitudes, $80 \%$ tinham disposição para executar 0 autocuidado. Partindo para a prática, averiguou-se que cuidados como lavagem, secagem, hidratação e massagem não eram executados juntos. É necessário o desenvolvimento de estratégias educativas para sensibilizar, tanto os diabéticos quanto os profissionais de saúde, para a eficaz prevenção do pé diabético.

Descritores: Diabetes Mellitus tipo 2. Pé diabético. Conhecimentos, atitudes e prática em saúde.

\section{RESUMEN}

Este estudio tuvo como objetivo identificar los conocimientos, actitudes y prácticas orientadas a la prevención del pie diabético en pacientes con diabetes mellitus tipo 2. Se trata de estudio transversal realizado en dos Unidades de Salud de la Familia, en la ciudad de Picos-PI, con 85 diabéticos de ambos sexos, mediante el uso de un formulario de encuesta semiestructurada conocimiento, Actitudes y Prácticas tipo. Hubo un predominio del sexo femenino en el estudio (62,4\%). En el conocimiento de cuidado de los pies, el 49,4\% no sabía cómo hacer la higiene y lo que quiere ver en los pies. En el cuidado de las uñas, el 56,5\% desconocía el corte correcto. En cuanto a las actitudes, el 80\% tuvo que realizar la prestación de cuidados personales. A partir de la práctica, se investigó que la atención como el lavado, secado, hidratación y masaje no se corrieron juntos. Es necesario desarrollar estrategias educativas para crear conciencia, tanto en diabéticos como profesionales de la salud, la prevención efectiva del pie diabético.

Descriptores: Diabetes Mellitus tipo 2. Pie diabético. Conocimientos, actitudes y práctica en salud.
D0l: http://dx.doi.org/10.1590/19831447.2014.03.45187

\footnotetext{
Student of Nursing at the Universidade Federal do Piauí (UFPI), Campus de Picos, Piauí, Brazil.

b Student of Nursing at the UFPI, Campus de Picos, Piauí, Brazil. PIBIC/CNPq Scholarship.

' Student of Nursing at the UFPI, Campus de Picos, Piauí, Brazil. Scholarship of the Tutorial Education Programme (PET).

${ }^{d}$ PhD. Statistician. Professor of the Graduate Programme at the Universidade Estadual do Ceará (UECE). Fortaleza, Ceará, Brazil.

e Master's degree. Nurse. Professor of the Bachelor's Course in Nursing at the UFPI, Campus de Picos, Piauí, Brazil.

f PhD. Nurse. Professor of the Bachelor's Course in Nursing at the UFPI, Campus de Picos, and Master's degree in Science and Health, Teresina, Piauí, Brazil.
} 


\section{口INTRODUCTION}

Among the degenerative chronic diseases with high mobri-mortality rates, Diabetes Mellitus (DM), especially type 2 (DM2), is steadily becoming a serious public health issue. Every year, incidence of this disease increases in the global population, generating onerous costs with treatment and the consequent worsening of the quality of life of people who suffer from this disease.

In light of this genesis of chronic complications, the most important and challenging issue for healthcare professionals who assist diabetics, and for the actual sufferers, is blood glucose control ${ }^{(1)}$. Hyperglycaemic rates usually lead to the early appearance of chronic complications such as retinopathy, nephropathy, neuropathy, coronary artery disease, cerebrovascular disease and peripheral vascular disease ${ }^{(2)}$.

Of the alterations mentioned above, diabetic neuropathy deserves special attention because it most commonly occurs during the natural course of the disease. Moreover, this disease has high incapacitation, mutilation and recurrence rates, generating high costs for both patients and the healthcare system. It is caused by the dysfunction of peripheral nerves resulting in a loss of sensitivity to heat, touch and pain due to the chronic hyperglycaemia of badly-controlled DM2 $2^{(2)}$. Withal, early identification of factors associated to the development of diabetic ulcers favours early and planned actions of healthcare professionals, especially the implementation of measures to delay the onset of these ulcers. Metabolic control, the education of patients with DM and frequent and effective foot examination are examples of these measures.

The purpose of nursing is the comprehensiveness of care. Nurses must be aware of the importance of offering quality care, observing aggravating circumstances of the health of their patients and accompanying control of the pathology. These are essential practices to prevent the appearance of diabetic foot and other complications of the disease. Diabetic foot is a physiopathological state with a etiopathogenic neuropathic basis, induced by sustained hyperglycaemia in which, with or without the co-existence of Peripheral Arterial Disease (PAD), and with a prior triggering trauma, ulcers and/or deep tissue destruction occur on the feet of diabetics ${ }^{(3)}$.

Preventive care provided by nurses to sufferers of diabetic foot involves several stages, but starts with the identification of patients at risk by means of a detailed clinical exam that observes: structural evaluation, investigation of neuropathy and distal pulse measurements. Once patient risk is identified, the patient must receive guidelines on risk factors and correct care procedures ${ }^{(4)}$.

Several studies emphasize the importance of nurses examining the feet of people with DM, focusing on evaluating the risk of complications, such as amputations ${ }^{(4-5)}$, and their primary-based care ${ }^{(6)}$, and correlating social and economic factors and educational activities for self-care by means of good blood sugar control ${ }^{(1,4-6)}$.

Consequently, the purpose of this study was to identify knowledge, attitudes and practices of care to prevent diabetic foot in patients with diabetes mellitus type 2, in two Family Care Units (USF), in the municipality of Picos, Piauí, Brazil.

\section{Q METHOD}

This is a cross-sectional, descriptive study conducted in two USF in the municipality of Picos, Piauí, Brazil, that has a Primary Care network of 30 USFs, of which 20 are in the urban area and 10 in the rural area.

The two USFs were chosen in the urban zone for convenience, as they had a greater number of users registered in the HIPERDIA programme. According to data from the Municipal Health Secretariat of the city, in September 2011, a total of 137 patients were registered in the HIPERDIA system at both USFs.

Inclusion criteria were: a DM2 diagnosis; both sexes; registered at the HIPERDIA of both health units selected for data collection; over 18 years of age. Criteria for exclusion were patients who were unable to provide the requested information during data collection, such as elderly patients who, together with the complications of cognitive problems, found it impossible to objectively answer the questionnaire, and/or patients with diabetic foot.

Convenience sampling was used and data were collected at the nursing room during consultations or home visits from March to April 2012, by means of a semi-structured Knowledge, Attitude and Practice (KAP) questionnaire, adapted from Souza $(2008)^{(7)}$. Before starting collection, a pilot test was conducted to adapt the questionnaire to the reality of the research subjects.

The questionnaire contained items to assess social, economic and clinical profiles, family history of DM2, years of conviviality with the pathology, drug and non-drug treatment, and questions related to knowledge of measures to prevent diabetic foot, attitudes to prevent it and self-care practices of the person with DM2.

Data were analysed in a database created using a Microsoft Office Excel $2007^{\mathrm{TM}}$ spreadsheet, and later transferred to SPSS (Statistical Package for the Social Sciences) version 
17.0 to calculate statistical measurements and standard deviation for variables addressed in the collection instrument.

This research proposal was submitted to the Research Ethics Committee of the Universidade Federal do Piauí, for ethical and methodological approval, registered under CAAE: 0419.0.045.000-11.

\section{RESULTS}

Of the 85 interviewees, $62.4 \%$ were women between the ages of 25 and $87,45.9 \%$ were married, 55.3\% were retired and $71.8 \%$ had a family income of up to two minimum wages.

During the interviews, when investigated on their knowledge regarding foot care, (Table 1), 49.4\% stated they did not know how to perform correct foot hygiene; $45.9 \%$ stated that drying should consist of passing a towel between their toes; $49.4 \%$ did not know what a person with diabetes should observe in their feet; and only $18.8 \%$ answered that comfortable and closed footwear is ideal. In relation to nail care, $56.5 \%$ did not know how to cut their nails correctly.

Table 1 - Knowledge of diabetics on preventive foot care, in two Family Health Unit. Picos, PI, Brazil.

\section{Variables}

\section{Correct Hygiene}

With cold water and regular soap 38.8

With cold water only 35

With warm water and neutral soap 9.4

I don't know

$\begin{array}{cc}2 & 2.4 \\ 8 & 9.4 \\ 42 & 49.4\end{array}$

\section{Ideal Drying}

With a towel, without drying between the toes

With a towel, drying between the toes

No need to dry

I don't know

40.0

\section{Observing your feet}

Only when there is callosity, tingling and numbness

Coloration, temperature, blisters, callosity, wounds, tingling and numbness

38.8

No need to observe feet

I don't know

49.4

Ideal Footwear

Tight

Loose

Comfortable and closed

Comfortable and open

41.2

Any type

I don't know

\section{Correct Nail Cutting}

Rounded

Straight

20.0

Either rounded or straight

I don't know 56.5

Source: Research data 
In terms of attitudes to prevent foot ulcers, (Table 2), most patients (82.4\%) would put the foot physical exam into practice if they received the necessary information; to prevent foot-related complications (80\%), once a week (50\%). When asked if they would engage in self-care foot practices, $80 \%$ answered positively; to prevent complications (98.5\%), performing self-care on their feet on a daily basis (57.4\%). In relation to using moisturizers or oils during foot care, $80 \%$ stated they would use them if provided; to prevent their feet from becoming dry (89.7\%); on a daily basis $75 \%$.

In relation to care to prevent chronic foot complications (Table 3), 100\% stated washing; $64.7 \%$ drying every time; $43.5 \%$ moisturizing; and $34.1 \%$ massaging feet. In terms of the most frequently used footwear, $87.1 \%$ used open sandals; and more than half stated they always inspected their footwear before use (54.1\%). When asked about the habit of cutting their nails, (91.8\%) answered positively, cutting in a rounded format (75.6\%) using a pointed-tip scissors (46.2\%).

Table 2 - Attitudes towards preventing diabetic foot ulcers of patients in two Family Health Units. Picos - Pl, Brazil.

\section{Variables}

\section{n}

$\%$

\section{Would perform physical examination}

$\begin{array}{lll}\text { Yes } & 70 & 82.4 \\ \text { No } & 15 & 17.6\end{array}$

\section{Why Perform Physical Examination}

To prevent foot-related complications $\quad 56 \quad 80.0$

To detect changes in feet

$14 \quad 20.0$

Would Engage in Self-Care

Yes

$68 \quad 80.0$

No

$17 \quad 20.0$

\section{Why Engage in Self-Care}

To prevent foot-related complications $\quad \begin{array}{ll}67 & 98.5\end{array}$

To detect changes in feet

$1 \quad 1.5$

Would Use Moisturizer or Oil

\begin{tabular}{lcc} 
Yes & 68 & 80.0 \\
No & 17 & 20.0 \\
To & & \\
To prevent feet from getting dry & 61 & 89.7 \\
To ensure good appearance of feet & 7 & 10.3 \\
\hline
\end{tabular}

Source: Research data
Table 4 shows the analysis of knowledge, attitudes and practices in relation to gender. Results showed that men statistically had more knowledge on the right footwear to use, being that 9 men answered comfortable and closed, with a significant difference between the sexes $(p=0.023)$. In relation to attitude, 46 women answered they would perform self-care. Thus, women showed they were more willing to include self-care practices in their routine ( $p=0.044$ ). Evaluating the parameters dry, moisturize and massage feet, women showed a significant difference in relation to men, with a significance of $p=0.002$,

Table 3 - Foot care practices performed by diabetics of two Family Health Units. Picos - PI, Brazil.

\section{Variables}

$\%$

\section{Foot care*}

$\begin{array}{lll}\text { Wash } & 85 & 100.0 \\ \text { Dry } & 55 & 64.7 \\ \text { Moisturize } & 37 & 43.5 \\ \text { Massage } & 29 & 34.1\end{array}$

Type of Habitually Used Footwear

Closed and tight

$3 \quad 3.5$

Open sandals

$74 \quad 87.1$

Closed and soft

$8 \quad 9.4$

Inspects Footwear Before Use

Always

Sometimes

20.0

Rarely

Never

Nail Cutting

Yes

No

91.8

$7 \quad 8.2$

Nail Cut

Rounded

$59 \quad 75.6$

Straight

$19 \quad 24.4$

\section{Cutting Instrument}

$\begin{array}{lll}\text { Pointed tip scissors } & 36 & 46.2\end{array}$

$\begin{array}{lll}\text { Cutter or penknife } & 1 & 1.3\end{array}$

$\begin{array}{lll}\text { Rounded tip scissors } & 12 & 15.4\end{array}$

Nail cutter

$29 \quad 37.2$


Table 4 - Relation between gender and knowledge, attitude and practices of people with diabetics of the two Family Health Units. Picos - PI, Brazil.

\begin{tabular}{lccc}
\multicolumn{1}{c}{ Variables } & Male (53) & Fex & P* \\
Type of Footwear & 1 & - & \\
$\quad$ Tight & 2 & 2 & \\
Loose & 9 & 7 & 0.023 \\
Comfortable and closed & 6 & 29 & \\
Comfortable and open & 4 & 2 & \\
Any type & 10 & 13 & \\
I don't know & & & \\
Would Perform Self-Care & 22 & 46 & 0.044 \\
Yes & 10 & 7 & - \\
No & & 53 & 0.002 \\
Foot care & 32 & 41 & 0.002 \\
Wash & 14 & 30 & 0.020 \\
Dry & 7 & 23 & \\
Moisturize & 6 & & \\
Massage & & & \\
\hline
\end{tabular}

Source: Research data

* Fisher's Exact Test

$p=0.002$ and $p=0.020$ respectively, being that of the 55 who stated they dried their feet, 41 were women; of the 37 who answered they moisturized their feet, 30 were women; and of the 29 who claimed to massage their feet, 23 were women.

\section{DISCUSSION}

Results showed that $49.4 \%$ did not know how to perform foot hygiene or what they should observe in their feet, 56.5\% did not know the correct way to cut their toe nails and $80 \%$ declared they were willing to perform self-care. In terms of practice, results showed that care practices, such as washing, drying, moisturizing and massaging were not performed together. It was also perceived that there was a predominance of women in relation to men, which could be explained by the fact that women are more concerned with health, had a greater perception of the disease and used the health service more often. This finding is not considered a new fact, and is in line with other studies on similar topics ${ }^{(8-11)}$. However, unlike the results of another study ${ }^{(11)}$, this study revealed that most diabetics, even after claiming they know how to perform hygiene correctly, could not explain which or how to adequately conduct these practices, and were also unaware of the ideal footwear and how to cut their toenails correctly.

Knowledge on the correct foot care can delay the onset of alterations that lead to ulcers and amputations, enable changes in incorrect behaviour and promote cooperation of patients in relation to treatment and, subsequently, self-care.

Although one of the competencies of nurses is to provide information and enable active attitudes in relation to the disease, especially in terms of lower limb care and the prevention of complications, patients must also incorporate the received information ${ }^{(12-13)}$.

When investigating attitude, the sample behaved satisfactorily in relation to the willingness to practice and follow guidelines to prevent diabetic foot. However, deficient knowledge, revealed by incorrect answers on the purpose of physical exams and their frequency and difficulties in detecting complications, deviates to inadequate practices and confirms the thesis that even in the case of diabetics 
with the correct attitude, insufficient knowledge leads to changes in the attitudes of patients in relation to the daily demands of treatment.

In terms of care and practices to prevent chronic complications of the feet, all the interviewees stated they practiced some foot hygiene method, albeit incomplete and/or inadequate, such as drying between the toes, nail cutting and the adopted instrument (pointed-tip scissors). These results are similar to those obtained in other studies ${ }^{(8,12-15)}$, which show inadequate self-care behaviour, although diabetics know that appropriate foot care is necessary. This disconnection between attitudes and self-care foot practices suggests a deficiency of previous knowledge, which can be related to the lack of access to information that should be provided by professionals of the USF, and to the non-conduction of physical exams or sensitivity tests on patient's feet during their consultations.

It is the responsibility of nurses, together with other healthcare professionals, to create educational measures (pamphlets, gatherings, home visits) to promote this type of knowledge for these users. Family members should also be involved in the care that this disease requires, to improve overall assistance ${ }^{(4,16)}$.

In this study, women were more willing to include selfcare practices in their routines, in addition to already moisturizing and massaging their lower limbs, which shows that women take better care of their feet. This finding can be related to local culture, which suggests that man do not need to take care of their feet as this practices is socially related to women.

\section{CONCLUSION}

This study enabled the evaluation of knowledge, attitudes and practices of diabetics in relation to self-care foot practices. These parameters are believed to be essential to asses the educational diagnosis of the study sample, considering that preventive actions can be planned once patients successfully adhere to self-care practices.

In relation to knowledge of study participants on foot care, results revealed a significant deficit level. In terms of attitude, however, a considerable disposition to practice self-examination and self-care was detected. In relation to practice, results showed that some important practices were not being conducted or were incomplete, which could be related to a lack of knowledge. The knowledge, attitude and practices triad must be interconnected in order to achieve successful preventive foot care.
Consequently, healthcare professionals must know the reality in which the diabetic is inserted to plan adequate interventions that enable an understanding of the offered information. In this way, educational interventions that approach the adoption of essential behaviour with regard to foot care are considered the ideal practices for this public, which should include daily foot examination and preventive care for skin, nails and callosity.

Professionals should incorporate the practice of health-related education in their daily routines to better assist their patients. Furthermore, as those responsible for promoting, protecting and recovering health, they are expected to obtain desirable results with diabetics in preventing and delaying the onset of foot complications and help diabetics to improve their quality of life.

\section{REFERENCES}

1. Araújo MFM, Gonçalves TC, Damasceno MMC, Caetano JA. Aderência de diabéticos ao tratamento medicamentoso com hipoglicemiantes orais. Esc Anna Nery Rev Enferm. 2010;14(2):361-7.

2. Sociedade Brasileira de Diabetes. Cuide bem dos seus pés e não pise na bola! [Internet]. São Paulo; 2011 [cited 2013 nov 28]. Available in: www.diabetes. org.br/colunistas-da-sbd/educacao/1637-cuide-bem-dos-seus-pes-e-nao-pise-na-bola.

3. Duarte N, Gonçalves N. Pé diabético. Angiol Cir Vasc. 2011;7(2):63-79.

4. Santos ICRV, Nunes ENS, Melo CA, Farias DG. Amputações por pé diabético e fatores sociais: implicações para cuidados preventivos de enfermagem. Rev Rene. 2011;12(4):684-91.

5. Karino ME, Pace AE. Risco para complicações em pés de trabalhadores portadores de diabetes mellitus. Cienc Cuid Saude. 2012;11(supl.):183-90.

6. Santos ICRV, Bezerra GC, Souza CL, Pereira LC. Pé diabético: apresentação clínica e relação com 0 atendimento na atenção básica. Rev Rene. 2011;12(2):393-400.

7. Souza, MA. Autocuidado na prevenção de lesões nos pés: conhecimento e prática de pacientes diabéticos [dissertação]. João Pessoa (PB): Universidade Federal da Paraíba; 2008.

8. Rocha RM, Zanetti ML, Santos MA. Comportamento e conhecimento: fundamentos para prevenção do pé diabético. Acta Paul Enferm. 2009;22(1):17-23.

9. Rodrigues, FFL, Zanetti ML, Santos MA, Martins TA, Souza VD, Teixeira CRS. Conhecimento e atitudes: componentes para a educação em diabetes. Rev Latino-Am Enfermagem. 2009;17(4):[7 telas].

10. Almeida AS, Silveira MM, Espírito Santo PF, Pereira RC, Salomé GM. Avaliação da qualidade de vida em pacientes com diabetes mellitus e pé ulcerado. Rev Bras Cir Plast. 2013;28(1):142-6.

11. Bragança CM, Gomes IC, Fonseca MRCC, Colmanetti MNS, Vieira MG, Souza MFM. Avaliação das práticas preventivas do pé diabético. J Health Sci Inst. 2010;28(2):159-63.

12. Pereira DA, Costa NMSC, Sousa ALL, Jardim PCBV, Zanini CRO. Efeito de intervenção educativa sobre o conhecimento da doença em pacientes com diabetes mellitus. Rev Latino-Am Enfermagem. 2012;20(3):[8 telas].

13. Cubas MR, Santos OM, RetzlaffEMA, Telma HLC, Andrade IPS, Moser ADL, Erzinger AR. Pé diabético: orientações e conhecimento sobre cuidados preventivos. Fisioter Mov. 2013;26(3):647-55. 
14. Amaral AS, Tavares DMS. Cuidados com os pés: conhecimento entre pessoas com diabetes mellitus. [Internet]. Rev Eletr Enf. 2009 [cited 2013 nov 28];11(4):80110. Available in: http://www.fen.ufg.br/revista/v11/n4/pdf/v11n4a05.pdf.

15. Andrade NHS, Dal Sasso-Mendes K, Faria HTG, Martins TA, Santos MA, Teixeira CRS, et al. Pacientes com diabetes mellitus: cuidados e preven- ção do pé diabético em atenção primária à saúde. Rev Enferm UERJ. 2010;18(4):616-21.

16. Cisneros LL, Gonçalves LA0. Educação terapêutica para diabéticos: os cuidados com os pés na realidade de pacientes e familiares. Cienc Saude Coletiva. 2011;16(Supl. 1):1505-14.

\section{Author's address:}

Ana Roberta Vilarouca da Silva

Rua Cícero Eduardo, 905, Junco

64600-000, Picos, PI

E mail:vilarouca@ufpi.edu.br
Received: 21.02.2014

Approved: 08.08.2014 